\title{
Health Problems Associated with Existing Indoor Air Quality in Tribal Household Kitchens
}

\author{
Pooja Arya*, Hemu Rathore and N. L. Panwar \\ Maharana Pratap University of Agriculture \&Technology, \\ Udaipur- 313001 (Rajasthan) India
}

\begin{abstract}
A B S T R A C T
Keywords

Biomass fuel, Household air pollution, Health problems, Indoor air quality, Traditional chulha etc

Article Info

Accepted:

10 August 2020

Available Online:

10 September 2020

Indoor air pollution which poses a critical threat to human health with ambient and household air pollution through exposure to pollutants in urban and rural areas in India. The present study was undertaken with the objective to assess the health problems faced by tribal household kitchens. The study was carried out in Udaipur district of Rajasthan state. A sample of hundred households i.e. 50 households from Challi Village and 50 households from Bisama village were selected randomly to explore the health problems associated with existing indoor air quality. For accomplishing the objectives of the present study, interview technique was used to get the information from the respondents. For this purpose an interview schedule was developed after extensive review of literature and in consultation with the subject matter specialists. Both health related problems and problems related to burning of fuel were found to be 'most severe' in nature at the time of using crop residues/twigs in traditional chulha. Health problems (3.22) found most severe in comparison to problems related to burning of fuel (3.11). Most of these problems are because of the smoke generated from the burning of biomass in traditional chulha.
\end{abstract}

\section{Introduction}

Energy is the key component to improve social and economic well-being of a nation and is indispensable to most industrial and commercial growth. With the advancement in science and technology and industrial development, the need of energy has increased manifold all over the world. Rural India diversified with the group of people, culture, tradition, and ways of living. It is said, the soul of India lives in its villages which constitute about $60 \%$ of India's total population. But, unfortunately, majority of rural people suffer from an unhealthy and unhygienic condition of life. Indoor air pollution is one of the key reasons for generating unsustainable living condition among the countryside household. However, through the Ministry of New and Renewable Energy (MNRE), a noble initiative of biomass improved cook stove has been introduced to get out of this miserable situation.

Indoor air pollution occurring from the combustion of biomass fuel in traditional cook stoves causes a significant public health 
hazard predominantly affecting poor rural and urban population in many developing countries. A large number of people are exposed daily to harmful emissions and other health risks during biomass burning, typically in low efficient traditional stoves having inadequate ventilation. Majority of those exposed to enhanced level of pollutants are women responsible for food preparation in kitchen, and infant/young children who spend time around the women near the cooking area.

Incomplete combustion of biomass releases 50 times more noxious pollutants like particulate matter, carbon monoxide, nitrogen dioxide, sulphur dioxide, formaldehyde and carcinogens such as benzo (a) pyrene and benzene and this is also responsible for death of 3 to 4 million peoples due to its combustion which are used by the rural and poor people of urban areas of the country (WHO, 2012). Globally 4.3 million people die every year from the exposure to traditional biomass combustion (WHO, 2014; Smith et al., 2014). More than 1.45 million people, mostly women and children under five years old, die prematurely each year from household air pollution due to inefficient biomass combustion (WHO, 2008).

The combustion efficiency of biomass fuels is also very low. Thus, it yields relatively high level of carbon particles from incomplete combustion which are more damaging to the health of women who spend several hours working in this smoke filled environment. The World Bank (2000) designated indoor air pollution in the developing countries as one of the most critical global environment problem.

Daily average of pollutant level emitted indoors often exceeded current WHO guidelines and acceptable levels. Although many hundreds of separate chemical agents have been identified in the smoke from biomass fuels, the four most serious pollutants are particulates, carbon monoxide, polycyclic organic matter, and formaldehyde.

Exposure to biomass smoke contributes significantly to numerous respiratory illness and diseases, include acute respiratory infection, chronic obstructive lung disease, and lung cancer. It is also a factor in pregnancy related complications (Naeher $e t$ al., 2007). A study on respiratory diseases revealed that a woman inhales smoke equal to 20 cigarettes per day while cooking on traditional chulha. Inside the kitchen, amount of total suspended particles present 1000 times greater chance to penetrate deep into our lungs of the inhabitants than the suspended particles outside the environment (Hildebrand, 2007).

Elevated indoor air pollution levels due to the burning of biomass fuel in developing countries are well established. Few studies have quantitatively assessed air pollution levels of traditional cook stoves and examined these measures in relation to health effects.

The main objectives of this study to explore the health problems associated with indoor air qualityin tribal household kitchens

\section{Materials and Methods}

An exploratory research design was used to analyze the present investigation. For the present investigation two tribal panchayatsamities i.e. Gogunda and sayra were selected purposively. From the selected panchayatsamities, one village from each panchayatsamitie namely Challi from Gogunda and Bisama from sayra were selected for the present study as these villages are adopted as smart villages by the MPUAT, Udaipur. A sample of hundred households i.e. 50 households from Challi Village and 50 households from Bisama village were selected randomly to explore the health hazards 
associated with existing indoor air quality. For accomplishing the objectives of the present study, interview technique was used to get the information from the respondents.

For this purpose an interview schedule was developed after extensive review of literature and in consultation with the subject matter specialists. To achieve the results of the present study, the information collected in each phase was scored, coded, categorized, converted into tables, calculated in percentage and analyzed through statistical analysis. Frequency, percentage, mean weighted score, mean percent score were used for analysis of the data statistically.

\section{Results and Discussion}

Biomass fuelis typically burnt in inefficient wood-stoves which produce high levels of indoor air pollution, exposing women and children to major health hazards like acute respiratory infection, chronic obstructive lung diseases and lung cancer. The poor combustion and inefficiency of traditional biomass cook stoves also has significant repercussions for the environment, both, in terms of deforestation and regional and global climate impacts.

\section{Health problems associated with existing indoor air quality in tribal household kitchens}

Exposure to IAP from burning solid fuel such as wood, dung, crop residues for cooking and heating causes the premature deaths of 4 million people each year(WHO, 2014). Inefficient combustion of biomass fuel and poorly regulated energy production are the major cause of air pollution, is considered as single most man-made effect (IEA, 2016).

Around $42.2 \%$ of the population is exposed to household air pollution in most of the middle and low-income countries and it ranks as the eighth greatest risk factor causing morbidity and mortality (World bank, 2016).

This section deals with the information of the respondent stribal household kitchens.

Scrutiny of Table 1 shows that majority of the respondents $(67.00 \%)$ had puccahouse. Twenty-three per cent respondents had mixed house and only 10.00 per cent of the respondents had kuccha house. Most of the respondents $(58.00 \%)$ had separate kitchen which had mixed (kuccha and pucca) construction while 19.00 and 16.00 per cent respondents had puccaor a kucchaseparate kitchen respectively. Only 7.00 per cent of the respondents had a small enclosure/half wall as kitchen. Regarding location of the kitchen, it was found that 42.00 per cent respondents had kitchen attached with room/verandah, followed by respondents who hadkitchen under the staircase $(33.00 \%)$, while one fourth of the respondents $(25.00 \%)$ had kitchen away from rooms or living area.

Regarding Facilities in the kitchen, Cent per cent respondents were using traditional chulha, while more than two-third of the total respondents (72.00\%) also used LPG stove as supplementary fuel. Only 11.00 and 5.00 per cent of the respondents used kerosene stove and electric heater respectively, along with traditional chulha.

It is further evident from Table 1 that majority of the respondents had wooden door to their kitchen $(43.00 \%)$ while 16.00 per cent of the respondents had door made from tin sheet. Forty-one per cent of the respondents had no door to their kitchen and they just left open space. Forty-seven per cent of the respondents were having window in their kitchen. More than one-fourth of the respondents $(28.00 \%)$ had window with wooden/glass door, followed by small percentage of respondents 
having windows fitted with wire mesh $(19.00 \%)$. Only seven per cent respondents had open window space in the wall. Majority of the respondents $(70.00 \%)$ also had ventilator in their kitchen while 35.00 per cent of respondents had open space for ventilator, followed by the respondents who had small holes for ventilation $(26.00 \%)$ and ventilator with wire mesh $(9.00 \%)$.

Regarding smoke outlet facility in the kitchen, only 43.00 per cent of the respondents had some provision of smoke outlet in the kitchen like holes in the wall $(21.00 \%)$, pipe $(15.00 \%)$ and having a hole in the roof $(7.00 \%)$. Majority of the respondents $(65.00 \%)$ had no water outlet provision from their kitchen while 35.00 per cent respondents had some form of water outlet facility in their kitchen (open drain- $16.00 \%$, covered drain- $11.00 \%$ and hole in the corner of the kitchen- $8.00 \%$ ).

Table 1 further depicts that majority of the respondents had built-in shelves $(72.0 \%)$ in their kitchen. Nearly half of the respondents had utensil rack/basket $(49.00 \%)$ and wooden cupboard with wire mesh on sides/door $(31.00 \%)$. Only 6.00 per cent of the respondents had built-in cupboard with door in their kitchen.

So it was concluded that majority of the respondents had pucca houses $(67.00 \%)$ with separate kitchens of mixed construction $(58.00 \%)$. Cent per cent respondents were using traditional chulha and biomass as fuel. These findings are supported by NSSO (200910) and Balkrishnan (2002). NSSO (2009-10) reported that in India, firewood (biomass) is still used as main source of energy for cooking by more than three-fourth of households $(76.30 \%)$. LPG is used by 72.00 per cent and dung cakes by 66.00 per cent of the households. (2002) found that majority of households were traditional stove users
(75.00\%). Parajuli (2012) also reported that the prevalence of traditional fuel use in the village was 100 per cent.

Though majority of the respondents had wooden doors $(43.00 \%)$, window $(54.00 \%)$ and ventilators $(70.00 \%)$ in their kitchen but provision of smoke outlet facility was found only in the kitchens of less than fifty per cent of the respondents (43.00\%). Regarding the storage facility, majority of the respondents had built in shelves in their kitchen. The findings point out that though there is improvement in kitchen structures none of the respondents had improved stoves with the presence of smoke outlet pipeline.

\section{Problems in use of crop residues/twigs}

Respondents were found to face several problems while using crop residues/twigs in traditional chulha. These problems were categorized as health-related problems and problems related to burning of fuels. These problems were also recorded on four point continuum scale viz. most severe, severe, least severe and no problem and analyzed in terms of weighted mean score (Table 2).

Health related problems seen 'most severe' as reported by the respondents were backache (3.87) as respondents had to sit in squatting posture for long, irritation in eyes (3.77) because of smoke and headache (3.70) because of the smoke generated from these fuels.

Respondents also experienced the problems of breathing (3.08) and cough (3.00) as 'most severe'. These were followed by other health related problems i.e., allergy from smoke (2.67), and burning of skin/rashes from fire (2.43) which were reported as 'severe'. 
Table.1 Type of house and kitchen $n=100$

\begin{tabular}{|c|c|c|}
\hline Sr. No. & Details & $\begin{array}{l}\text { Percent } \\
\text { age }\end{array}$ \\
\hline 1. & Type of house & \\
\hline a) & Kuchha & 10 \\
\hline b) & Pucca & 67 \\
\hline c) & Mixed & 23 \\
\hline 2. & Type of kitchen & \\
\hline a) & Separate kuchha kitchen & 16 \\
\hline b) & Separate mixed kitchen & 58 \\
\hline c) & Separate pucca kitchen & 19 \\
\hline d) & Small enclosure/half wall & 7 \\
\hline 3. & Location of the kitchen & \\
\hline a) & Attached with rooms/verandah & 42 \\
\hline b) & Away from rooms/living area & 25 \\
\hline c) & Under the staircase & 33 \\
\hline 4. & Facilities in the kitchen & \\
\hline i. & Type of chulha* & \\
\hline a) & Traditional chulha & 100 \\
\hline b) & Kerosene stove & 11 \\
\hline c) & LPG stove & 72 \\
\hline d) & Electric heater & 5 \\
\hline ii. & Provision of door & \\
\hline a) & Wooden door & 43 \\
\hline b) & Tin door & 16 \\
\hline c) & No door (only open space) & 41 \\
\hline iii. . & Provision of window & \\
\hline a) & Window with wire mesh & 19 \\
\hline b) & Window with wooden /glass door & 28 \\
\hline c) & Open space in the wall & 7 \\
\hline iv. & Provision of ventilator & \\
\hline a) & Ventilator with wire mesh/glass & 9 \\
\hline b) & Open space & 35 \\
\hline c) & Holes for ventilator & 26 \\
\hline v. & Provision of smoke outlet & \\
\hline a) & Pipe for smoke outlet & 15 \\
\hline b) & Hole in the roof for smoke outlet & 7 \\
\hline c) & Holes in the wall for smoke outlet & 21 \\
\hline vi. & Provision of water outlet & \\
\hline a) & Hole in kitchen corner & 8 \\
\hline b) & Open drainage & 16 \\
\hline c) & Covered drainage & 11 \\
\hline vii. & Storage Facility in the kitchen & \\
\hline 1. & Built in cupboard with door & 6 \\
\hline 2. & Built in shelves & 72 \\
\hline 3. & $\begin{array}{l}\text { Wooden cupboard with wire mesh on sides } \\
\text { and/or door }\end{array}$ & 31 \\
\hline 4. & Utensil rack/ basket & 49 \\
\hline
\end{tabular}


Table.2 Problems faced by respondents in use of crop residue/twigs $n=100$

\begin{tabular}{|c|c|c|c|c|c|c|}
\hline $\begin{array}{l}\text { Sr. } \\
\text { No. }\end{array}$ & Problems & $\begin{array}{l}\text { Most } \\
\text { severe }\end{array}$ & Severe & $\begin{array}{l}\text { Least } \\
\text { severe }\end{array}$ & $\begin{array}{c}\text { No } \\
\text { problem }\end{array}$ & WMS \\
\hline 1. & Health Problems & & & & & \\
\hline i. & Headache & 81 & 11 & 5 & 3 & 3.70 \\
\hline ii. & Backache & 87 & 13 & - & - & 3.87 \\
\hline iii. & Irritation in eyes & 84 & 9 & 7 & - & 3.77 \\
\hline iv. & Cough & 31 & 43 & 21 & 5 & 3.00 \\
\hline v. & Respiratory problems & 27 & 58 & 11 & 4 & 3.08 \\
\hline vi. & Smoke allergy & 16 & 42 & 35 & 7 & 2.67 \\
\hline \multirow[t]{2}{*}{ vii. } & $\begin{array}{l}\text { Burning of skin/rashes from } \\
\text { fire }\end{array}$ & 12 & 33 & 41 & 14 & 2.43 \\
\hline & & & & & & 3.22 \\
\hline 2. & Burning of fuel & & & & & \\
\hline i. & Wastage of fuel & 83 & 17 & - & - & 3.83 \\
\hline ii. & More smoke generation & 68 & 24 & 3 & 5 & 3.55 \\
\hline iii. & Difficulty in initial burning & 64 & 25 & 2 & 9 & 3.44 \\
\hline iv. & More time consumption & 59 & 31 & 8 & 2 & 3.47 \\
\hline v. & Produce more ash & 49 & 41 & 4 & 6 & 3.33 \\
\hline vi. & $\begin{array}{l}\text { Blackening of walls and } \\
\text { ceiling }\end{array}$ & 72 & 9 & 7 & 12 & 3.41 \\
\hline vii. & $\begin{array}{l}\text { Deposition of soot on the } \\
\text { utensils }\end{array}$ & 63 & 15 & 13 & 9 & 3.32 \\
\hline viii. & $\begin{array}{l}\text { Inconvenience in } \\
\text { maintaining fire }\end{array}$ & 49 & 34 & 12 & 5 & 3.27 \\
\hline ix. & Requires frequent blowing & 31 & 43 & 19 & 7 & 2.98 \\
\hline $\mathrm{x}$. & Uncleanliness in kitchen & 48 & 12 & 23 & 17 & 2.91 \\
\hline xi. & Risk of burn & 28 & 22 & 38 & 12 & 2.66 \\
\hline xii. & Fear of fire & 14 & 8 & 67 & 11 & 2.25 \\
\hline xiii. & $\begin{array}{l}\text { Deposition of soot on } \\
\text { clothes }\end{array}$ & 12 & 14 & 33 & 41 & 1.97 \\
\hline & & & & & & 3.11 \\
\hline
\end{tabular}

Respondents also expressed some problems while burning fuel. 'Most severe' problems faced by the respondents were wastage of fuel in traditional chulha (3.83), emission of excessive smoke (3.55), time consuming process of igniting fuel (3.47),difficulty in initial igniting of crop residues/twigs (3.44) and production of ash in large quantity (3.33). Other 'most severe' problems, as reported by the respondents, were blackening of walls/ceiling and utensils because of deposition of soot (3.41 and 3.32 respectively), difficulty in maintaining constant fire/flame (3.27). Other problems related to burning of crop residues/twigs faced by the respondents and analyzed as 'severe' in nature were need for frequent blowing of air by mouth through funkni (2.98), lack of cleanliness in kitchen (2.91), risk/fear of burn (2.66), fear of fire in nearby 
stored fuel (2.25) and followed by 'least severe' problem i.e. deposition of soot on clothes (1.97).

Conclusively, both health related problems and problems related to burning of fuel were found to be 'most severe' in nature. However, health problems (3.22) most severe in comparison to problems related to burning of fuel (3.11). Most of these problems are because of the smoke generated from the burning of biomass in traditional chulha. Respondents faced many problems in using crop residues/twigs in traditional chulha. 'Most severe' health related problems found by the respondents were headache, backache, irritation in eyes, cough and breathing problems. While other problems like wastage of fuel, emission of more smoke, difficulty in initial igniting of fuel, time consuming process, production of ash in large quantity, blackening of walls/ceiling and utensils were also observed. Mehta (2002) also supported these findings whofound that the main problem in use of traditional chulha was cleaning/maintenance problems, followed by health problems and problem in use. Cleaning/maintenance related problems were 'blackening of wall/ceiling', 'deposition of soot on the utensils' and 'uncleanliness in kitchen'. Health problems were mainly irritation in eyes, cough, respiratory problems, headache, low visibility and smoke generation.

Thus, it can be concluded that Majority of the respondents had pucca houses (67\%) with separate kitchens of mixed construction (58.00\%) attached with rooms/verandah (42\%). Cent per cent respondents were using traditional chulha as main cooking stove, though they also had LPG stove (72.00\%). They had wooden doors $(43.00 \%)$, window $(54.00 \%)$ and ventilators $(70.00 \%)$ in their kitchen but provision of smoke outlet facility was found only in the kitchens of less than fifty per cent of the respondents (43.00\%). Regarding the storage facility, majority of the respondents had built in shelves in their kitchen. The findings point out that though there is improvement in kitchen structures none of the respondents had improved stoves with the presence of smoke outlet pipeleine. Both health related problems and problems related to burning of fuel were found to be 'most severe' in nature at the time of using crop residues/twigs in traditional chulha. However, health problems (3.22) most severe in comparison to problems related to burning of fuel (3.11). Most of these problems are because of the smoke generated from the burning of biomass in traditional chulha.

\section{References}

Balkrishnan, L. 1997. Rural women and renewable energy. Journal of Social Welfare. 44(7): 35-37.

Hildebrand, A. 2007. Indoor air pollution is the biggest killer. Times of India. 22March, p. 5.

IEA (2016). Energy \& Air Pollution. International Energy Agency, Paris. Improved wood stove and traditional house-stone stove in rural Kenya. Biomass Bioenergy 2013.

Naeher, L. P., Brauer, M. and Lipsett, M. 2007. Woodsmoke health effects: a review. Inhal Toxicology. 19: 67-106.

NSSO. 2009 -10. Energy sources of Indian households for cooking and lighting. Ministry of statistics and programme implementation. GoI. Pp. 33-35.

Parajuli, Y. G. 2012. The assessment of indoor air pollution associated with household fuel use in Bangalkot district, Karnataka, India. Global Journal of Medical and Public Health. 1(2): 33-38.

Smith, K. R., Bruce, N., Balakrishnan, K., Adair Rohani, H., Balmes, J. and Chafe, Z. 2014. Millions dead: how do 
we know and what does it mean? Methods used in the comparative risk assessment of household air pollution. Annual Review of Public Health. 35: 185-206.

WHO. 2008. The global burden of disease: 2004 update. Geneva, Switzerland: World Health Organization. Retrieved from

http://www.who.int/healthinfo/global_ burden_ disease/2004_report_update len. Dated 25.07.2018

WHO. 2012. Health effects of black carbon.
Regional Office for Europe. Retrieved from http: //www.euro.who.int/Pubrequest. Dated 25/07/2018.

WHO. 2014. Indoor Air Quality Guidelines: Household Fuel Combustion. Retrieved from http://apps.who.int/iris/bitstream/1066 5/141496/1/9789241548885_eng.pdf. Dated 25.07.2018.

World Bank. 2000. Household energy, air pollution and health. Retrieved from UNDP/ESMAP.

\section{How to cite this article:}

Pooja Arya, Hemu Rathore and Panwar, N. L. 2020. Health Problems Associated with Existing Indoor Air Quality in Tribal Household Kitchens. Int.J.Curr.Microbiol.App.Sci. 9(09): 809816. doi: https://doi.org/10.20546/ijcmas.2020.909.102 